\title{
Pharmacopoeia Researches and Antimicrobial Activity Studies on Matricaria chamomilla L.
}

\author{
Meryem Ozdemir ${ }^{1}$, Sevda Suzgec-Selcuk ${ }^{2}$, Emel Mataracı-Kara ${ }^{3}$, Berna Ozbek-Celik ${ }^{3}$ \\ ${ }^{1}$ Sivas Cumhuriyet University, Faculty of Pharmacy, Department of Pharmacognosy, Sivas, Turkey. \\ ${ }^{1}$ Istanbul University, Graduate School of Health Sciences, Istanbul, Turkey. \\ ${ }^{2}$ Istanbul University, Faculty of Pharmacy, Department of Pharmacognosy, Istanbul, Turkey. \\ ${ }^{3}$ Istanbul University, Faculty of Pharmacy, Department of Pharmaceutical Microbiology, Istanbul, Turkey. \\ Correspondence Author: Sevda Suzgec-Selcuk \\ E-mail: ssuzgecselcuk@istanbul.edu.tr
}

Received: 22.05.2021 Accepted: 03.11.2021

\begin{abstract}
Objective: The aim of this study is to compare Matricaria chamomilla samples collected from nature and supplied from pharmacies and herbalists by performing quality control analyses and investigate the antimicrobial activities of them.

Methods: These samples were examined according to Matricariae flos monograph analysis in European Pharmacopoeia. Macroscopic and microscopic examination, loss on drying and total ash experiment were performed. Essential oil was obtained from the drugs and analyzed by thin layer chromatography. Additionally, aqueous and ethanolic extracts of all samples were compared by thin layer chromatography. Antimicrobial activity was determined by microdilution method in aqueous and ethanolic extracts.

Results: According to the pharmacopoeia analysis; in macroscopic and microscopic examinations, all samples except 2 herbalist samples were found to suitable for the pharmacopoeia standards. In loss on drying, none of the samples were found to suitable for the standards except 2 herbalist samples. In total ash, all samples were suitable for the standards. While the essential oil of $M$. chamomilla samples collected from nature was yellow-orange colored, we obtained the blue essential oil containing chamazulene from pharmacy samples and 3 of herbalist samples. The highest activity in antimicrobial activity assay was observed in ethanol extracts against Staphylococcus aureus, Staphylococcus epidermidis and Candida tropicalis strains.

Conclusion: Examples of true M. chamomilla were found among herbalist samples, contrary to the previous studies. Pharmacy samples were qualified but limited in terms of variety. Essential oil analyses pointed out the importance of geographical location among natural samples. Antimicrobial activity tests did not provide significant results.
\end{abstract}

Keywords: Matricaria chamomilla, Chamomile, Pharmacopoeia analysis, Antimicrobial activity

\section{INTRODUCTION}

Matricaria chamomilla L. is a member of the Asteraceae family and known by names such as "Mayıs papatyası, Tibbi papatya, Adi papatya, Babunç, Akbubaç, Papatya and Papaçya" in Turkey $(1,2)$. The name of the plant is a combination of the words "chamos" meaning place in Greek and "malos" meaning apple, as it grows on the ground and the scent of its fresh flowers reminds of the smell of apples (3). M. chamomilla grows naturally in Southern and Eastern Europe, Western Asia, North America and Australia. Chamomile is abundant in roadsides and in empty fields in Turkey $(1,4)$.

Matricariae flos are shade-dried capitulums of $M$. chamomilla. According to studies on the chemical composition of $M$. chamomilla, the plant contains mainly flavonoids (apigenin, luteolin, chrysoeriol, apigenin-7-O-glucoside, apigenin glucoside acetate, luteolin-7-O-glucoside, rutin, hyperoside, isorhamnetin, patuletin, jaceidinem), phenolic compounds, essential oil (chamazulene, (-)- $\alpha$-bisabolol, bisabolol oxide $A$, bisabolol oxide $B$, bisabolone oxide $A,(E)$ - $\beta$-farnesene, $(E)$ - and (Z)-spiroethers, spathulenol), hydroxy coumarins (umbelliferone, herniarin) and sesquiterpene lactones (matricin, matricarin and desacetylmetricarin). Plant also contains mucilage, polysaccharides, amino acids, fatty acids, triterpene hydrocarbons, tannin and choline (3-6). Chamazulene, which is formed by the hydrolysis of matricin during distillation, gives the essential oil a blue color $(5,6)$. It has been observed that some Anatolian-origin chamomile don't contain chamazulene in their essential oils. The essential oils of Turkey-origin drugs are rich in bisabolon oxide and bisabolol oxide (1). 
The plant is commonly used internally as a diuretic, an appetite-stimulant, a carminative and a cholagogue in public. Externally, it is used for the treatment of throat inflammation, hemorrhoids, abscess and acne (1). M. chamomilla has antiinflammatory, antispasmodic, antimicrobial, antiviral and mild sedative effects. In the German Commission E monographs, it is approved for use in fevers and colds, cough, bronchitis, tendency to infection, inflammation of the skin, inflammation of the mouth and pharynx, wounds and burns $(5,6)$.

There are many biological activity studies on M. chamomilla. Among these studies, antimicrobial, antioxidant and antiinflammatory activity studies are the most common (7-10). In addition, studies on wound healing, anxiolytic, antispasmodic, anticancer, analgesic, antiallergic, antihyperglycemic and antiparasitic effects are also included in the literature. Further, the effects on stomach, mucosa and memory are studied (1119). Recent antimicrobial activity studies on M. chamomilla mainly performed with its' extracts which obtained by using various solvents and extraction techniques or essential oil of the plant. Staphylococcus aureus, Escherichia coli, Pseudomonas aeruginosa, Bacillus subtilis, Bacillus cereus and Salmonella typhi bacterial strains and Candida albicans, Aspergillus flavus and Aspergillus niger fungal strains were the most common strains in these studies $(7,8,20-31)$.

Today, there are many plants are considered as chamomile by mistake, because of their similarity to chamomile. These plants include Anthemis, Bellis, Tanacetum, Tripleurospermum and Chrysanthemum species (32). Accidental use of some of these species, instead of Matricaria, may cause serious problems for human health.

Medicinal plants are generally obtained from herbalists, markets, online stores and chain stores, rarely collected from nature and supplied from pharmacies. Usually, complete form of the plants can be collected from nature or supplied from pharmacies and herbalists. To understand the differences among these three resources, in this study, quality control analyses were performed on chamomile samples obtained from 5 herbalists in Istanbul, 2 Matricariae flos obtained from pharmacies and $M$. chamomilla capitulum samples collected from 3 different regions in Istanbul, based on the monograph of Matricariae flos in the European Pharmacopoeia (EP) (33). Since it is a widely used drug in phytotherapy, the investigation of the antimicrobial activities of ethanolic and aqueous extracts of all samples was also included in this study.

\section{METHODS}

\subsection{Materials}

Diethyl ether, ethanol, chloroform, methanol, n-hexane, toluene, sulfuric acid were obtained from Merck (Darmstadt, Germany). Benzene and ethyl acetate were from Riedel-deHaën (Seelze, Germany). Vanillin, acetaldehyde and Roswell Park Memorial Institute (RPMI) medium were from SigmaAldrich (Steinheim, Germany). Mueller-Hinton broth were obtained from Difco (Detroid, Michigan, USA).

\subsection{Plant Materials}

Samples sold as "medicinal chamomile" were purchased from 5 different herbalists randomly selected in Istanbul. M. chamomilla drugs were obtained from 2 different companies whose products are only sold in pharmacies. Also, M. chamomilla samples were collected from Çatalca and 2 different regions in Çekmeköy in Istanbul (Turkey) in May 2018. The collected plant samples were determined by Emine Akalın Uruşak (Istanbul University Faculty of Pharmacy Department of Pharmaceutical Botany). Voucher specimens were deposited in the Herbarium of the Istanbul University Faculty of Pharmacy (ISTE: 115521, 115522, 115654). The flowering parts of the collected plants were dried in the shade. The drug samples used in this study were coded as MD1, MD2, MD3 for the samples collected from nature, ME1 and ME2 for pharmacy samples and MA1, MA2, MA3, MA4 and MA5 for herbalist samples.

\subsection{Macroscopic Analysis}

Morphological characteristics of flower specimens were examined using a Leica S8APO stereomicroscope (Leica, Wetzlar, Germany). Capitulum, involucre, receptacle, ray and disc florets parts were analyzed according to pharmacopoeia standards. The capitulum sizes of the samples were measured with a ruler.

\subsection{Microscopic Analysis}

The preparations prepared using chloral hydrate reagent from powdered drug samples were determined under microscope (Olympus CX21FS1, Olympus Corporation, Tokyo, Japan) using 10x and 40x lenses. Characteristic elements for Matricariae flos such as pollen grains, stigma, glandular trichomes were examined $(33,34)$.

\subsection{Loss on Drying}

Glass weighing bottles were kept in the drying oven and then cooled in a desiccator to constant weight. $1 \mathrm{~g}$ of each sample was weighed in tared bottles and dried in the drying oven at $105{ }^{\circ} \mathrm{C}$ for 2 hours. Then bottles were cooled in a desiccator, reweighed and the percentage of weight loss was calculated.

\subsection{Total Ash}

The crucibles were heated for 30 minutes and then cooled in a desiccator to constant weight. $1 \mathrm{~g}$ drug from each sample was weighed in the tared crucibles. After drying at $105{ }^{\circ} \mathrm{C}$ for one hour, it was burned in an ashing furnace (Protherm PC442T, Protherm Furnaces, Ankara, Turkey) at $600{ }^{\circ} \mathrm{C}$. Then the crucibles were cooled in a desiccator, weighed and the percentage of total ash was calculated.

\subsection{Isolation of Essential Oil}

Essential oil was isolated using clevenger apparatus according to the distillation method in the EP. 50 grams of chamomile drug was put into a $1000 \mathrm{~mL}$ balloon. $500 \mathrm{~mL}$ of distilled water was added on it. After 3 hours of distillation, the volume of 
essential oil was measured. The isolated essential oil was stored at $+4{ }^{\circ} \mathrm{C}$ until it was used.

\subsection{Preparation of the Extracts}

$5 \%$ ethanolic and aqueous extracts of all M. chamomilla samples were prepared by 3 different methods. For the 1st method (P); $20 \mathrm{~g}$ drug was extracted using ethanol (400 $\mathrm{mL})$ in percolator for 24 hours. In the 2 nd one (E5); $5 \mathrm{~g}$ drug was macerated using ethanol $(100 \mathrm{~mL})$ for 24 hours and shaked in a magnetic stirrer (Dragon Lab MS-H-S, DLAB, Beijing, China) for 4 hours. After extraction, both samples were filtered. Then the ethanol was evaporated under reduced pressure at $45{ }^{\circ} \mathrm{C}$ using rotary evaporator (Buchi R-210, Flawil, Switzerland). For the 3rd method (S); 5 g drug was macerated using distilled water $(100 \mathrm{~mL})$ for 24 hours and shaked in a magnetic stirrer for 4 hours. The extract was filtered and lyophilized (Labconco Free Zone 4.5, Labconco, Kansas City, MO, USA). The crude extracts were used in TLC analysis and antimicrobial activity assays.

\subsection{Thin Layer Chromatography (TLC) of Extracts and Essential Oils}

TLC analyses of essential oils and extracts were performed according to the "Matricariae flos" monograph in the EP. In addition, 2 different mobile phase systems which used for the TLC analysis of $M$. chamomilla in the literature were also included in this study (35). Essential oils were dissolved in hexane. $20 \mathrm{mg}$ of each extracts were dissolved in methanol (2 $\mathrm{mL}$ ). Silica gel TLC plate (Silicagel 60F254, Merck, Darmstadt, Germany) was used as the stationary phase. Ethyl acetatetoluene (5:95), chloroform-toluene (75:25) and chloroformtoluene-ethyl acetate (65:30:5) solvent mixtures were used as mobile phase. Anisaldehyde-sulfuric acid reagent was used for ethyl acetate-toluene (5:95) mobile phase system, and vanillinsulfuric acid reagent was used for chloroform-toluene (75:25) and chloroform-toluene-ethyl acetate (65:30:5) mobile phase systems. After the reagents were sprayed, the plates were heated at $105^{\circ} \mathrm{C}$ for 10 minutes. They were examined under daylight and UV light (254-366 nm).

\subsection{Antimicrobial Activity}

The antimicrobial activities of all of the aqueous and ethanol extracts of Matricariae flos samples were examined by the Department of Pharmaceutical Microbiology, Faculty of Pharmacy, Istanbul University. The microorganisms used in this study were; Staphylococcus aureus ATCC 6538, Staphylococcus epidermidis ATCC 12228, Escherichia coli ATCC 25922, Enterococcus faecalis ATCC 29212, Klebsiella pneumoniae ATCC 4352, Pseudomonas aeruginosa ATCC 27853, Proteus mirabilis ATCC 14153, Candida tropicalis ATCC 750, Candida parapsilosis ATCC 22019 and Candida albicans ATCC 1023. Minimum Inhibitory Concentration (MIC) values were determined by microdilution method according to the Clinical Laboratory Standards Institute (CLSI) guidelines $(36,37)$.
A $5 \times 10^{5}$ colony forming unit $(\mathrm{cfu}) / \mathrm{mL}$ bacterial inoculum was sampled from 4-6 hours culture in Mueller-Hinton broth medium. A $2.5 \times 10^{3} \mathrm{cfu} / \mathrm{mL}$ inoculum of Candida species was sampled from 24 hours culture in RPMI-1640 medium which buffered with 3-(N-morpholino) propanesulfonic acid (MOPS).

The microplates were incubated for $18-24$ hours at $35^{\circ} \mathrm{C}$ for bacteria and for $46-50$ hours at $35{ }^{\circ} \mathrm{C}$ for Candida species. The lowest concentration of substance that prevents visible growth was determined as the MIC value. Cefuroxime, Ceftazidime, Amikacin, Clotrimazole and Amphotericin B were used as reference antimicrobial agents.

\section{RESULTS}

\subsection{Macroscobic Analysis}

Disc florets of all plants were yellow, ray florets were white. Expect MA4 and MA5, all of the involucral bracts had brownish-grey scarious margins. For MA4 and MA5 bracts had white and none-scarious margins. Expect MA4 and MA5, all of the receptacles were elongated-conical or hemispherical (for young capitula). MA4 and MA5 had generally flat or slightly curved receptacles. The receptacle of 2 herbalist samples (MA4 and MA5) was hollow, with paleae. Capitulum size, number of ray and disc florets, other specifications of involucre and receptacle are demonstrated in the Table 1.

Table 1. Morphological properties of samples.

\begin{tabular}{|c|c|c|c|c|c|c|}
\hline Samples & $\begin{array}{l}\text { Capitulum } \\
\text { sizes }\end{array}$ & $\begin{array}{c}\text { Incolucral } \\
\text { bracts }\end{array}$ & $\begin{array}{l}\text { Involucral } \\
\text { bracts }\end{array}$ & Receptacle & $\begin{array}{l}\text { Ray } \\
\text { florets }\end{array}$ & $\begin{array}{l}\text { Disc } \\
\text { florets }\end{array}$ \\
\hline MD1 & $0,4-0,5 \mathrm{~cm}$ & Ovate & $1-2$ rows & $\begin{array}{l}\text { Without } \\
\text { paleae, } \\
\text { hollow }\end{array}$ & $15-18$ & $\begin{array}{l}\text { Several } \\
\text { dozen }\end{array}$ \\
\hline MD2 & $0,4-0,6 \mathrm{~cm}$ & $\begin{array}{c}\text { Ovate- } \\
\text { lanceolate }\end{array}$ & $2-3$ rows & $\begin{array}{l}\text { Without } \\
\text { paleae, } \\
\text { hollow }\end{array}$ & $12-15$ & $\begin{array}{c}\text { Several } \\
\text { dozen }\end{array}$ \\
\hline MD3 & $0,4-, 0,5 \mathrm{~cm}$ & $\begin{array}{c}\text { Ovate- } \\
\text { lanceolate }\end{array}$ & $2-3$ rows & $\begin{array}{l}\text { Without } \\
\text { paleae, } \\
\text { hollow }\end{array}$ & $12-15$ & $\begin{array}{l}\text { Several } \\
\text { dozen }\end{array}$ \\
\hline ME1 & $0,4-0,6 \mathrm{~cm}$ & Ovate & $2-3$ rows & $\begin{array}{l}\text { Without } \\
\text { paleae, } \\
\text { hollow }\end{array}$ & $18-21$ & $\begin{array}{l}\text { Several } \\
\text { dozen }\end{array}$ \\
\hline ME2 & $0,4-0,75 \mathrm{~cm}$ & $\begin{array}{c}\text { Ovate- } \\
\text { lanceolate }\end{array}$ & $1-2$ rows & $\begin{array}{l}\text { Without } \\
\text { paleae, } \\
\text { hollow }\end{array}$ & $18-21$ & $\begin{array}{l}\text { Several } \\
\text { dozen }\end{array}$ \\
\hline MA1 & $0,5-0,7 \mathrm{~cm}$ & Ovate & $1-2$ rows & $\begin{array}{l}\text { Without } \\
\text { paleae, } \\
\text { hollow }\end{array}$ & $18-20$ & $\begin{array}{l}\text { Several } \\
\text { dozen }\end{array}$ \\
\hline MA2 & $0,5-0,8 \mathrm{~cm}$ & $\begin{array}{c}\text { Ovate- } \\
\text { lanceolate }\end{array}$ & $1-2$ rows & $\begin{array}{l}\text { Without } \\
\text { paleae, } \\
\text { hollow }\end{array}$ & $16-18$ & $\begin{array}{l}\text { Several } \\
\text { dozen }\end{array}$ \\
\hline MA3 & $0,45-0,7 \mathrm{~cm}$ & $\begin{array}{c}\text { Ovate- } \\
\text { lanceolate }\end{array}$ & $1-2$ rows & $\begin{array}{l}\text { Without } \\
\text { paleae, } \\
\text { hollow }\end{array}$ & $\begin{array}{c}\text { Were } \\
\text { not } \\
\text { intact }\end{array}$ & $\begin{array}{l}\text { Several } \\
\text { dozen }\end{array}$ \\
\hline MA4 & $0,7-1,2 \mathrm{~cm}$ & Ovate & $1-2$ rows & $\begin{array}{l}\text { With paleae, } \\
\text { full }\end{array}$ & $14-17$ & $\begin{array}{c}\text { Several } \\
\text { dozen }\end{array}$ \\
\hline MA5 & $0,7-0,9 \mathrm{~cm}$ & Ovate & $1-2$ rows & $\begin{array}{l}\text { With paleae, } \\
\text { full }\end{array}$ & $16-18$ & $\begin{array}{l}\text { Several } \\
\text { dozen }\end{array}$ \\
\hline
\end{tabular}

MD1, MD2, MD3: the samples collected from nature; ME1, ME2: pharmacy samples; MA1, MA2, MA3, MA4, MA5: herbalist samples. 


\subsection{Microscobic Analysis}

Druse crystals in the inner tissues of the ovaries and the anther lobes, glandular trichomes, stigma, pollen grains with 3 pores, inner and outer epidermis of the corolla of the ray florets and corolla of the disc florets were seen in all samples. Covering trichomes and papillae were detected in MA4 and MA5 samples on the contrary of the other samples (Figure 1).

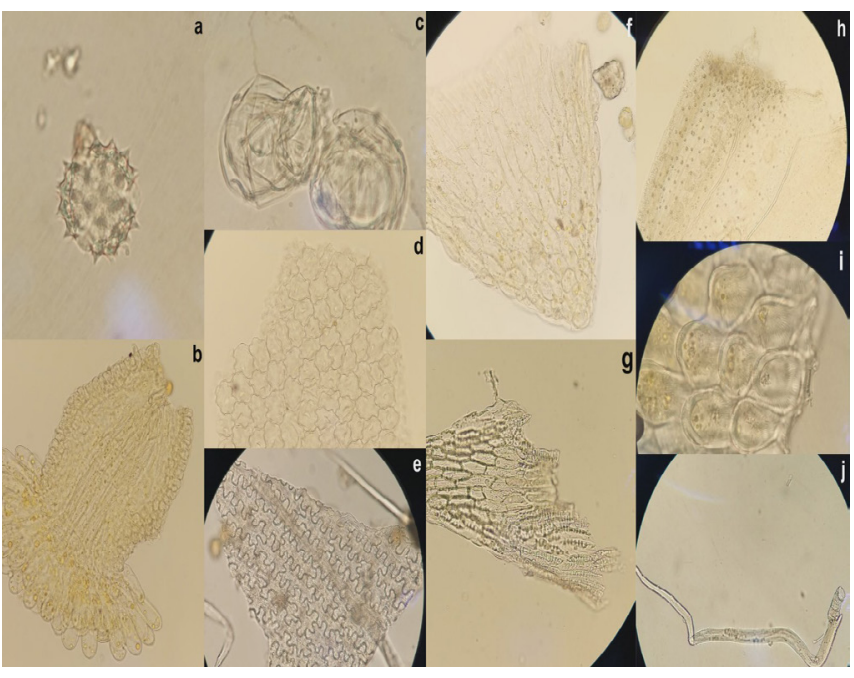

Figure 1. Microscope images of the samples (a) pollen in MA5; (b) stigma in ME1; (c) glandular trichomes in MA3; (d) inner epidermis of the corolla of the ray florets in ME2; (e) outer epidermis of the corolla of the ray florets MA4; $(f)$ corolla of the disc florets MD3; (g) anther in MD2; (h) druse in ME2; (i) papillae in MA4; (j) covering trichome in MA4.

\subsection{Loss on Drying and Total Ash}

In the "Matricariae flos" monograph, weight loss after drying is specified as max $12 \%$ and the total amount of ash is specified as $\max 13 \%$. It was determined that the total ash amount of all samples remained below standard value. However, it was observed that the moisture content of all samples except for MA4 and MA5 were above $12 \%$ (Table 2).

Table 2. Results of analyses of loss on drying and total ash.

\begin{tabular}{|c|c|c|}
\hline Samples & Loss on Drying (\%) & Total Ash (\%) \\
\hline MD1 & 13,0112 & 8,7123 \\
\hline MD2 & 15,5977 & 9,0199 \\
\hline MD3 & 14,4521 & 10,642 \\
\hline ME1 & 14,2476 & 10,1841 \\
\hline ME2 & 15,3156 & 9,6448 \\
\hline MA1 & 14,4579 & 9,5455 \\
\hline MA2 & 14,9551 & 9,1168 \\
\hline MA3 & 14,2757 & 12,0265 \\
\hline MA4 & 11,4349 & 10,9044 \\
\hline MA5 & 11,0601 & 12,1064 \\
\hline
\end{tabular}

MD1, MD2, MD3: the samples collected from nature; ME1, ME2: pharmacy samples; MA1, MA2, MA3, MA4, MA5: herbalist samples.

\subsection{Essential Oil Isolation}

Essential oil was obtained from the samples which identified as $M$. chamomilla after our analyses. While the distillation of pharmacy and herbalist samples of $M$. chamomilla resulted with blue essential oil, the distillation of samples collected from nature of $M$. chamomilla resulted with yellow-orange essential oil. According to the pharmacopoeia, a dry drug should contain at least $4 \mathrm{~mL} / \mathrm{kg}$ of blue essential oil. The volume of essential oil was determined as $0.6-0.8 \% \mathrm{~mL}$ in the samples collected from nature, $0.4-0.5 \% \mathrm{~mL}$ in pharmacy samples and $0.4-0.6 \% \mathrm{~mL}$ in herbalist samples.

\subsection{Thin Layer Chromatography (TLC)}

As a result of the TLC analysis of essential oils according to the pharmacopoeia method, it was observed that the essential oils of samples collected from nature did not contain chamazulene. Bornyl acetate and (-)- $\alpha$-bisabolol zones specified in the pharmacopoeia were detected in all essential oil samples (Figure 2).

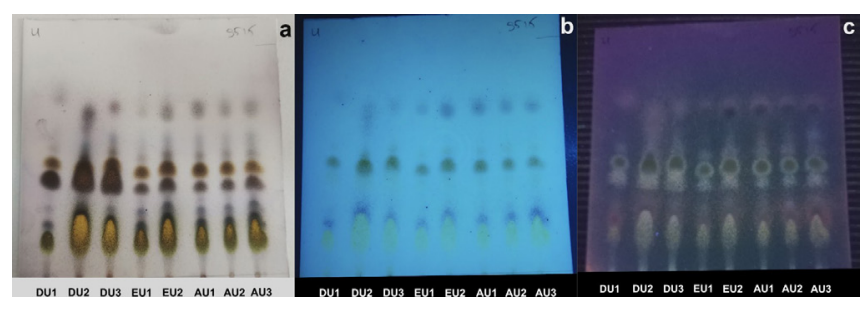

Figure 2. TLC chromatogram-1 visualized (a) under white light; (b) at $254 \mathrm{~nm}$; (c) at $366 \mathrm{~nm}$. Mobile phase: ethyl acetate-toluene (5:95); derivatization: Anisaldehyde-sulfuric acid reagent. DU1, DU2, DU3: essential oils of the samples collected from nature; EU1, EU2: essential oils of pharmacy samples; AU1, AU2, AU3: essential oils of herbalist samples.

As a result of TLC analysis using chloroform-toluene (75:25) and chloroform-toluene-ethyl acetate (65:30:5) mobile phase systems, the retention factor (Rf) values of cis-enin-dicycloether and chamazulene were accordant with the literature (35). $\mathrm{Rf}$ values are given in the Table 3. Chamazulene zone was not detected in the chromatograms of samples collected from nature. Selected TLC chromatograms are presented in Figures 3-7.

Table 3. Rf values of essential oil samples.

\begin{tabular}{|l|c|c|c|c|} 
& \multicolumn{2}{|c|}{$\begin{array}{c}\text { Chloroform-toluene (75:25) } \\
\text { mobile phase system }\end{array}$} & $\begin{array}{c}\text { Chloroform-toluene-ethyl } \\
\text { acetate (65:30:5) mobile } \\
\text { phase system }\end{array}$ \\
\hline & Rf1 & Rf2 & Rf1 & Rf2 \\
\hline DU1 & - & 0,58125 & - & 0,6125 \\
\hline DU2 & - & 0,5875 & - & 0,6 \\
\hline DU3 & - & 0,6 & - & 0,60625 \\
\hline EU1 & 0,74375 & 0,59375 & 0,725 & 0,5875 \\
\hline EU2 & 0,74375 & 0,6 & 0,7375 & 0,6 \\
\hline AU1 & 0,75 & 0,6 & 0,7375 & 0,60625 \\
\hline AU2 & 0,74375 & 0,6 & 0,7375 & 0,6 \\
\hline AU3 & 0,75 & 0,6 & 0,7375 & 0,60625 \\
\hline
\end{tabular}

DU1, DU2, DU3: essential oils of the samples collected from nature; EU1, EU2: essential oils of pharmacy samples; AU1, AU2, AU3: essential oils of herbalist samples. 


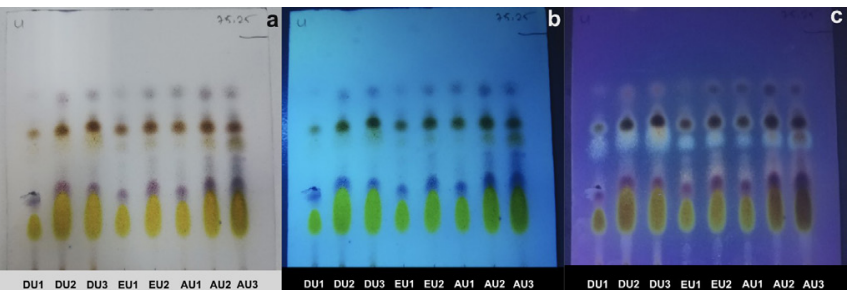

Figure 3. TLC chromatogram-2 visualized (a) under white light; (b) at $254 \mathrm{~nm}$; (c) at $366 \mathrm{~nm}$. Mobile phase: chloroform-toluene (75:25); derivatization: Vanillin-sulfuric acid reagent. DU1, DU2, DU3: essential oils of the samples collected from nature; EU1, EU2: essential oils of pharmacy samples; AU1, AU2, AU3: essential oils of herbalist samples.

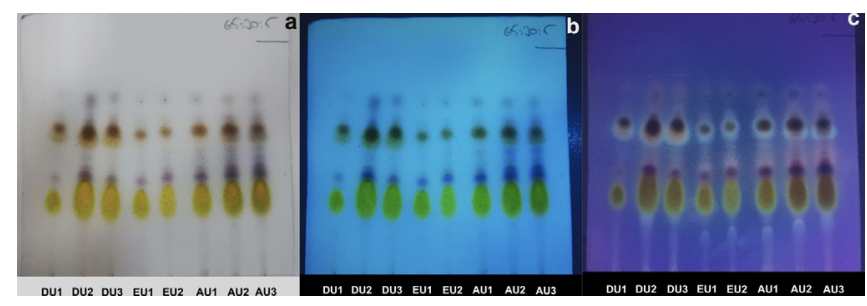

Figure 4. TLC chromatogram-3 visualized (a) under white light; (b) at $254 \mathrm{~nm}$; (c) at $366 \mathrm{~nm}$. Mobile phase: chloroform-toluene-ethyl acetate (65:30:5); derivatization: Vanillin-sulfuric acid reagent. DU1, DU2, DU3: essential oils of the samples collected from nature; EU1, EU2: essential oils of pharmacy samples; AU1, AU2, AU3: essential oils of herbalist samples.

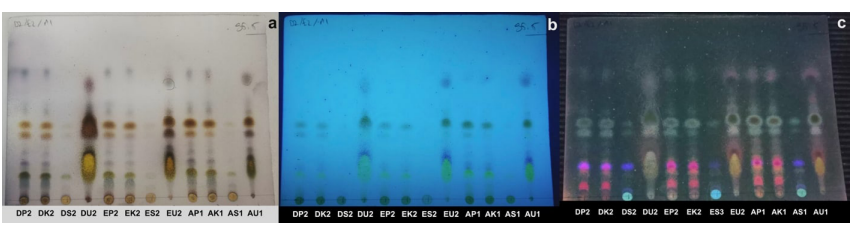

Figure 5. TLC chromatogram-4 visualized (a) under white light; (b) at $254 \mathrm{~nm}$; (c) at $366 \mathrm{~nm}$. Mobile phase: ethyl acetate-toluene (5:95); derivatization: Anisaldehyde-sulfuric acid reagent.

From MD2 sample (collected from nature): (DP2) Ethanol extract prepared by the 1st extraction method; (DK2) Ethanol extract prepared by the 2nd extraction method; (DS2) aqueous extract; (DU2) essential oil. From ME2 pharmacy sample: (EP2) Ethanol extract prepared by the 1st extraction method; (EK2) Ethanol extract prepared by the 2nd extraction method; (ES2) aqueous extract; (EU2) essential oil. From MA1 herbalist sample: (AP1) Ethanol extract prepared by the 1st extraction method; (AK1) Ethanol extract prepared by the 2nd extraction method; (AS1) aqueous extract; (AU1) essential oil.

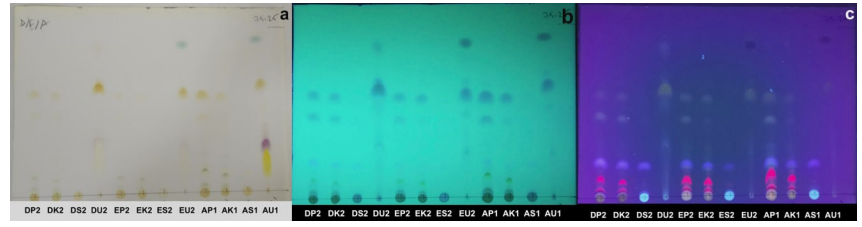

Figure 6. TLC chromatogram-5 visualized (a) under white light; (b) at $254 \mathrm{~nm}$; (c) at $366 \mathrm{~nm}$. Mobile phase: chloroform-toluene (75:25); derivatization: Vanillin-sulfuric acid reagent.

From MD2 sample (collected from nature): (DP2) Ethanol extract prepared by the 1st extraction method; (DK2) Ethanol extract prepared by the 2nd extraction method; (DS2) aqueous extract; (DU2) essential oil. From ME2 pharmacy sample: (EP2) Ethanol extract prepared by the 1st extraction method; (EK2) Ethanol extract prepared by the 2nd extraction method; (ES2) aqueous extract; (EU2) essential oil. From MA1 herbalist sample: (AP1) Ethanol extract prepared by the 1st extraction method; (AK1) Ethanol extract prepared by the 2nd extraction method; (AS1) aqueous extract; (AU1) essential oil.

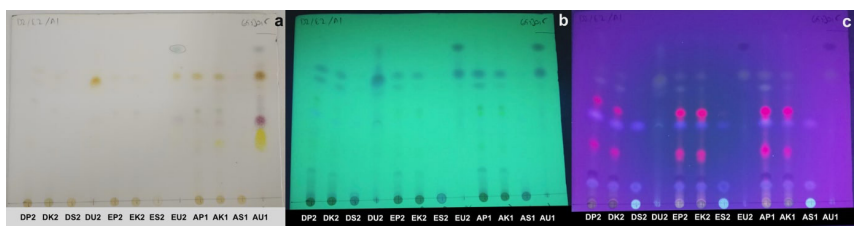

Figure 7. TLC chromatogram-6 visualized (a) under white light; (b) at $254 \mathrm{~nm}$; (c) at $366 \mathrm{~nm}$. Mobile phase: chloroform-toluene-ethyl acetate (65:30:5); derivatization: Vanillin-sulfuric acid reagent.

From MD2 sample (collected from nature): (DP2) Ethanol extract prepared by the 1st extraction method; (DK2) Ethanol extract prepared by the 2nd extraction method; (DS2) aqueous extract; (DU2) essential oil. From ME2 pharmacy sample: (EP2) Ethanol extract prepared by the 1st extraction method; (EK2) Ethanol extract prepared by the 2nd extraction method; (ES2) aqueous extract; (EU2) essential oil. From MA1 herbalist sample: (AP1) Ethanol extract prepared by the 1st extraction method; (AK1) Ethanol extract prepared by the 2nd extraction method; (AS1) aqueous extract; (AU1) essential oil.

\subsection{Antimicrobial Activity}

According to the results of the antimicrobial activity tests, all extracts showed antibacterial activity against $S$. aureus strain and the highest activity was detected in $M A 1_{p}$ extract with a MIC value of $312.5 \mu \mathrm{g} / \mathrm{mL}$. The highest activity against $S$. epidermidis strain was detected in $\mathrm{MD} 2_{E 5}, \mathrm{ME}_{\mathrm{P}}$ and $\mathrm{ME} 1_{\mathrm{E} 5}$ extracts with a MIC value of $625 \mu \mathrm{g} / \mathrm{mL}$. Against $E$. faecalis strain, it was detected in $M E 1_{E 5}$ and $M A 3_{E 5}$ extracts with a MIC value of $625 \mu \mathrm{g} / \mathrm{mL}$. Only the aqueous extracts of the MD1 and MD3 samples showed antibacterial activity against $E$. coli strain with a MIC value of $1250 \mu \mathrm{g} / \mathrm{mL}$. In our study, it was determined that none of the extracts showed antibacterial activity against $P$. aeruginosa, $K$. pneumoniae and $P$. mirabilis strains. Antifungal activity against fungal strains was observed only in extracts prepared from herbalist samples. As a result of the antimicrobial activity assay, it was found that the highest antimicrobial activity was in the ethanol extracts prepared with a magnetic stirrer after maceration with ethanol (Table 4). 
Table 4. Antimicrobial activity results of samples.

\begin{tabular}{|c|c|c|c|c|c|c|c|}
\hline & $\begin{array}{c}\text { S. aureus ATCC } \\
29213\end{array}$ & $\begin{array}{l}\text { S. epidermidis } \\
\text { ATCC } 12228\end{array}$ & $\begin{array}{c}\text { E. coli ATCC } \\
25922\end{array}$ & $\begin{array}{c}\text { E. faecalis ATCC } \\
29212\end{array}$ & $\begin{array}{c}\text { C. albicans ATCC } \\
10231\end{array}$ & $\begin{array}{l}\text { C. parapsilosis } \\
\text { ATCC } 22019\end{array}$ & $\begin{array}{c}\text { C. tropicalis ATCC } \\
750\end{array}$ \\
\hline MD1 $_{p}$ & 1250 & 1250 & - & - & - & - & - \\
\hline $\mathrm{MD1}_{\mathrm{E} 5}$ & 625 & 1250 & - & - & - & - & - \\
\hline MD1 $_{\mathrm{s}}$ & 1250 & - & 1250 & - & - & - & - \\
\hline $\mathrm{MD2}_{\mathrm{p}}$ & 1250 & 1250 & - & - & - & - & - \\
\hline $\mathrm{MD2}_{\mathrm{E5}}$ & 1250 & 625 & - & - & - & - & - \\
\hline $\mathrm{MD2}_{\mathrm{s}}$ & 1250 & - & - & - & - & - & - \\
\hline MD3 $_{p}$ & 1250 & 1250 & - & 1250 & - & - & - \\
\hline $\mathrm{MD3}_{\mathrm{E} 5}$ & 625 & 1250 & - & 1250 & - & - & - \\
\hline $\mathrm{MD3}_{\mathrm{S}}$ & 1250 & - & 1250 & - & - & - & - \\
\hline ME1 $_{p}$ & 1250 & 625 & - & 1250 & - & - & - \\
\hline $\mathrm{ME1}_{\mathrm{E5}}$ & 1250 & 625 & - & 625 & - & - & - \\
\hline $\mathrm{ME1}_{\mathrm{S}}$ & 1250 & - & - & - & - & - & - \\
\hline ME2 & 1250 & 1250 & - & 1250 & - & - & - \\
\hline ME2 ${ }_{E 5}$ & 1250 & 1250 & - & 1250 & - & - & - \\
\hline $\mathrm{ME2}_{\mathrm{s}}$ & 1250 & - & - & - & - & - & - \\
\hline$M A 1_{p}$ & 312,5 & 1250 & - & - & - & - & - \\
\hline$M A 1_{E 5}$ & 625 & 1250 & - & - & - & 312,5 & 312,5 \\
\hline $\mathrm{MA1}_{\mathrm{s}}$ & 1250 & - & - & - & - & - & 312,5 \\
\hline$M A 2_{p}$ & 1250 & 1250 & - & - & - & - & - \\
\hline$M A 2_{E 5}$ & 1250 & 1250 & - & - & - & - & 312,5 \\
\hline $\mathrm{MA2}_{\mathrm{S}}$ & 1250 & - & - & - & - & - & - \\
\hline$M A 3_{p}$ & 1250 & 1250 & - & 1250 & - & - & - \\
\hline$M A 3_{E 5}$ & 1250 & 1250 & - & 625 & - & - & 312,5 \\
\hline $\mathrm{MAB}_{\mathrm{S}}$ & 1250 & - & - & - & 625 & - & - \\
\hline Cefuroxime & 1,2 & 9,8 & 4,9 & - & - & - & - \\
\hline Amikacin & - & - & - & 128 & - & - & - \\
\hline Clotrimazole & - & - & - & - & 4,9 & - & - \\
\hline Amphotericin B & - & - & - & - & - & 0,5 & 1 \\
\hline
\end{tabular}

MD1, MD2, MD3: the samples collected from nature; ME1, ME2: pharmacy samples; MA1, MA2, MA3, MA4, MA5: herbalist samples. P: ethanolic extract prepared with the 1st extraction method, E5: ethanolic extract prepared with the 2nd extraction method, S: aqueous extract

(Since antimicrobial activity was not detected against $P$. aeruginosa, K. pneumoniae and $P$. mirabilis strains, these strains were not included in the table.)

\section{DISCUSSION}

In this study, quality control analyses were performed on a total of 10 samples, including $3 \mathrm{M}$. chamomilla samples collected from nature, 2 Matricariae flos drugs obtained from the pharmacy and 5 chamomile samples taken from the herbalist, according to the EP.

As a result of macroscopic and microscopic examinations, all of the samples collected from nature and supplied from pharmacies were determined as Matricaria chamomilla. Among the 5 herbal samples, 3 were determined as $M$. chamomilla, but 2 samples did not meet the pharmacopoeia standards. As a result of the macroscopic and microscopic examinations, the samples were thought to be Anthemis, Chamaemelum, Tanacetum or Bellis, but could not be identified because they had only flowering parts. Thus, these two samples (MA4 and MA5) were not included in the essential oil, TLC and antimicrobial activity analyses. On the other hand, the loss of drying value of all samples except two herbalist samples (MA4 and MA5) was found to be higher than pharmacopoeia standards. The total ash amount of all samples conformed to the standards.

M. chamomillla is considered as an aromatic plant because its' flowers contain essential oil. It was observed that the volume of essential oil obtained from the samples collected from nature was higher than the volume of the essential oil of pharmacy and herbalist samples. The volume of essential oil of freshly collected samples was higher than that of the other samples. It is confirmed that the time of collection of medicinal and aromatic plants containing essential oil is important for essential oil yield. Yellow-orange essential oil, which was isolated from the samples collected from nature by distillation, indicates that these samples do not contain chamazulene. The fact that no blue essential oil was detected in the analyzed samples collected from nature is compatible with the literature $(1,38)$. Blue essential oil containing chamazulene was obtained from pharmacy and herbalist samples. TLC analyses also confirmed these findings.

Our study is the first study in which M. chamomilla samples collected from nature, obtained from pharmacy and herbalist were analyzed together and compared with each other according to the EP. Three of 5 different herbalist samples were identified as $M$. chamomilla. Identification of these 3 samples, which also contain blue essential oil, is a positive result. However, our study has limited number of herbalist samples from a certain region, thus, it is hard to claim that most of the herbalists in Turkey provide true M. chamomilla plants. 
During the time of this study, there were only 2 medicinal drugs for $M$. chamomilla which sold in pharmacies, thus, to create a comparable group of samples, we preferred to limit the number of herbalist samples to 5 .

In our study, the antimicrobial activity test were also performed on all samples determined as $M$. chamomilla. The highest activity was observed in ethanolic extracts against $S$. aureus, $S$. epidermidis and $C$. tropicalis strains. These results are consistent with the literature data $(7,20,28)$. However, the activity levels in our study were not as high as the activity levels in the similar studies on M. chamomilla. The difference in collection time and geographical location or extraction methods may have caused this inconsistency.

\section{CONCLUSION}

This study examined ten different $M$. chamomilla samples from three different resources to compare their qualifications based on EP. Contrary to the literature and conventinal knowledge, this study showed that $M$. chamomilla also can be found in some of the herbal stores and can meet the EP standardards. Pharmacy samples also meet the EP standards in our study, however there were only two of them. This limited availability and variety might divert people from pharmacies to other resources. In terms of natural resources, this study demonstrated once again geographical location is important for the medicinal plants' chemical composition such as presence of blue essential oil. Lastly, antimicrobial activity tests did not provide significant results in our study.

To achieve more significant and generalisable results, studies with more pharmacy samples can be conducted, natural samples can be collected from wider regions, number of herbalist samples can be increased. Also, different extraction methods could be useful for further studies.

Funding: No funding.

Conflict of interest: The authors declare that they have no conflict of interest.

\section{REFERENCES}

[1] Baytop T. Therapy with Medicinal Plants in Turkey. 2nd ed. Istanbul: Nobel Medical Publishing; 1999.

[2] Tuzlacı E. A Dictionary of Turkish Plants, Türkiye Bitkileri Sözlüğü. İstanbul: Alfa Yayınları; 2011.

[3] Blumenthal M, Goldberg A, Brinckmann J. Herbal Medicine: Expanded Commission E Monographs. Newton, Massachusetts: Integrative Medicine Communications; 2000.

[4] Bisset NG. Herbal Drugs and Phytopharmaceuticals. Stuttgart: Medpharm Scientific Publishers; 1994.

[5] Gruenwald J, Brendler T, Jaenicek C. PDR for Herbal Medicines. 2nd ed. Montvale, New Jersey: Medical Economics Company; 2000.

[6] Barnes J, Anderson LA, Phillipson JD. Herbal Medicines. 3rd ed. Chicago: Pharmaceutical Press; 2007.

[7] Roby $M H H$, Sarhan MA, Selim KAH, Khalel KI. Antioxidant and antimicrobial activities of essential oil and extracts of fennel (Foeniculum vulgare L.) and chamomile (Matricaria chamomilla L.). Ind Crop Prod 2013; 44:437-445.

[8] Göger G, Demirci B, Ilgın S, Demirci F. Antimicrobial and toxicity profiles evaluation of the chamomile (Matricaria recutita L.) essential oil combination with standard antimicrobial agents. Ind Crop Prod 2018; 120:279-285.

[9] Flemming $M$, Kraus $B$, Rascle $A$, Jürgenliemk $G$, Fuchs $S$, Fürst R, Heilmann J. Revisited anti-inflammatory activity of matricine in vitro: Comparison with chamazulene. Fitoterapia 2015; 106:122-128.

[10] Cvetanović A, Švarc-Gajić J, Zeković Z, Jerković J, Zengin G, Gašić $U$, Tešić Ž, Mašković $P$, Soares C, Barroso MF, Delerue-Matos $C$, Đurović $S$. The influence of the extraction temperature on polyphenolic profiles and bioactivity of chamomile (Matricaria chamomilla L.) subcritical water extracts. Food Chem 2019; 271:328-337.

[11] Nayak BS, Raju SS, Rao AV. Wound healing activity of Matricaria recutita L. extract. J Wound Care 2007; 16(7):298-302.

[12] Sampaio TPD, Holmes TSV, De Medeiros Nóbrega DR, Dos Santos MGC, Bento PM, De Castro Gomes DQ, Pereira JV. Matricaria recutita Linn. in the prevention and control of radio-induced oral mucositis. Oral Surg Oral Med Oral Pathol Oral Radiol 2014; 117(2):e215.

[13] Jabri MA, Aissani N, Tounsi H, Sakly M, Marzouki L, Sebai $\mathrm{H}$. Protective effect of chamomile (Matricaria recutita L.) decoction extract against alcohol-induced injury in rat gastric mucosa. Pathophysiology 2017; 24(1):1-8.

[14] Yazdi H, Seifi A, Changizi S, Khori V, Hossini F, Davarian A, Jand $\mathrm{Y}$, Enayati A, Mazandarani M, Nanvabashi F. Hydro-alcoholic extract of Matricaria recutita exhibited dual anti-spasmodic effect via modulation of $\mathrm{Ca}^{2+}$ channels, NO and PKA - kinase pathway in rabbit jejunum. Avicenna J Phytomed 2017; 7(4):334-344.

[15] Hajaji S, Sifaoui I, López-Arencibia A, Reyes-Batlle $M$, Jiménez IA, Bazzocchi IL, Valladares B, Akkarari H, Lorenzo-Morales J, Piñero JE. Leishmanicidal activity of $\alpha$-bisabolol from Tunisian chamomile essential oil. ParasitoL Res 2018; 117(9):28552867.

[16] Prasanna R, Ashraf EA, Essam MA. Chamomile and oregano extracts synergistically exhibit antihyperglycemic, antihyperlipidemic, and renal protective effects in alloxaninduced diabetic rats. Can J Physiol Pharmacol 2017; 95(1):8492.

[17] Ionita R, Postu PA, Mihasan M, Gorgan DL, Hancianu M, Cioanca O, Hritcu L. Ameliorative effects of Matricaria chamomilla L. hydroalcoholic extract on scopolamine-induced memory impairment in rats: A behavioral and molecular study. Phytomedicine 2018; 47:113-120.

[18] Chandrashekhar VM, Halagali KS, Nidavani RB, Shalavadi MH, Biradar BS, Biswas D, Muchchandi IS. Anti-allergic activity of German chamomile (Matricaria recutita L.) in mast cell mediated allergy model. J Ethnopharmacol 2011; 137(1):336340.

[19] Zargaran A, Borhani-Haghighi A, Salehi-Marzijarani M, Faridi P, Daneshamouz S, Azadi A, Sadeghpour H, Sakhteman A, Mohagheghzadeh A. Evaluation of the effect of topical chamomile (Matricaria chamomilla L.) oleogel as pain relief in migraine without aura: A randomized, double-blind, placebocontrolled, crossover study. Neurol Sci 2018; 39(8):1345-1353.

[20] Abdoul-Latif FM, Mohamed N, Edou P, Ali AA, Djama SO, Obame LC, Bassole HN, Dicko MH. Antimicrobial and 
antioxidant activities of essential oil and methanol extract of Matricaria chamomilla L. from Djibouti. J Med Plant Res 2011; 5(9):512-1517.

[21] Mekonnen A, Yitayew B, Tesema A, Taddese S. In vitro antimicrobial activity of essential oil of Thymus schimperi, Matricaria chamomilla, Eucalyptus globulus, and Rosmarinus officinalis. Int J Microbiol 2016; 2016.

[22] İlkimen H, Gülbandılar A. Lavanta, ada çayı, kekik ve papatya ekstrelerinin antimikrobiyal etkilerinin araştırılması. Turk Microbiol Cem Derg 2018; 48(4):241-246.

[23] Tolouee M, Alinezhad S, Saberi R, Eslamifar A, Zad SJ, Jaimand K, Taeb J, Rezaee MB, Kawachi M, Shams-Ghahfarokhi M. Effect of Matricaria chamomilla L. flower essential oil on the growth and ultrastructure of Aspergillus niger van Tieghem. Int J Food Microbiol 2010; 139(3):127-133.

[24] Kazemi M. Chemical composition and antimicrobial activity of essential oil of Matricaria recutita. Int J Food Prop 2015; 17(11).

[25] Jamalian A, Shams-Ghahfarokhi M, Jaimand K, Pashootan N, Amani A, Razzaghi-Abyaneh M. Chemical composition and antifungal activity of Matricaria recutita flower essential oil against medically important dermatophytes and soil-borne pathogens. J Mycol Med 2012; 22(4):308-315.

[26] Rahman H, Chandra A. Microbiologic evaluation of Matricaria and chlorhexidine against $E$. faecalis and $C$. albicans. Indian J Dent 2015; 6(2):60.

[27] Vora J, Srivastava A, Modi H. Antibacterial and antioxidant strategies for acne treatment through plant extracts. Inform Med Unlocked 2018; 13:128-132.

[28] Cvetanović A, Švarc-Gajić J, Mašković P, Savić S, Nikolić L. Antioxidant and biological activity of chamomile extracts obtained by different techniques: perspective of using superheated water for isolation of biologically active compounds. Ind Crop Prod 2015; 65:582-591.

[29] Munir N, Iqbal AS, Altaf I, Bashir R, Sharif N, Saleem F, Naz S. Evaluation of antioxidant and antimicrobial potential of two endangered plant species Atropa belladonna and Matricaria chamomilla. Afr J Tradit Complement Altern Med 2014; 11(5):111-117.

[30] Serpi M, Ozdemir ZO, Salman Y. Investigation of the antibacterial effects of some plant extracts on Propionibacterium acnes. KSU J Agric Nat 2012; 15(1):7-12.

[31] Jafarzadeh MM, Moghaddam MJM, Bakhshi D. Antimicrobial activity of three plant species against multi-drug resistant E. coli causing urinary tract infection. J Herb Med 2020; 22:100352.

[32] Guzelmeric E, Vovk I, Yesilada E. Development and validation of an HPTLC method for apigenin 7-O-glucoside in chamomile flowers and its application for fingerprint discrimination of chamomile-like materials. J Pharm Biomed Anal 2015; 107:108-118.

[33] European Pharmacopoeia 7th ed. Council of Europe, Strasbourg, France; 2011.

[34] Baytop A. Bitkisel Drogların Anatomik Yapısı. İstanbul: İstanbul Üniversitesi Eczacılık Fakültesi Yayınları; 1975.

[35] Abdelhameed RM, Abdel-Gawad H, Taha M, Hegazi B. Separation of bioactive chamazulene from chamomile extract using metal-organic framework. J Pharm Biomed Anal 2017; 146:126-134.

[36] Clinical Laboratory Standards Institute (CLSI). Reference Method for Broth Dilution Antifungal Susceptibility Testing of Yeasts: Approved Standard M27-A NCCLS. Wayne, Pennsylvania; 2000.

[37] Clinical Laboratory Standards Institute (CLSI). Methods for Dilution Antimicrobial Susceptibility Tests for Bacteria That Grow Aerobically: Approved Standard M7-A5. Wayne, Pennsylvania; 2006.

[38] Mericli AH. The lipophilic compounds of a Turkish Matricaria chamomilla variety with no chamazulene in the volatile oil. Pharm Biol 1990; 28(2):145-147.

How to cite this article: Ozdemir M, Selcuk Suzgec S, Kara Mataracı E, Celik Ozbek B. Pharmacopoeia Researches and Antimicrobial Activity Studies on Matricaria chamomilla L. Clin Exp Health Sci 2021; 11: 801-808. DOI: 10.33808/clinexphealthsci.940847 